University of Nebraska - Lincoln

DigitalCommons@University of Nebraska - Lincoln

Agronomy \& Horticulture -- Faculty Publications

Agronomy and Horticulture Department

1995

\title{
Velvetleaf (Abutilon theophrasti) Recruitment, Survival,Seed Production, and Interference in Soybean (Glycine max)
}

John L. Lindquist

University of Nebraska-Lincoln, jlindquist1@unl.edu

Bruce Maxwell

Montana State University

Douglas Buhler

University of Minnesota

Jeffrey Gunsolus

University of Minnesota

Follow this and additional works at: https://digitalcommons.unl.edu/agronomyfacpub

Part of the Plant Sciences Commons

Lindquist, John L.; Maxwell, Bruce; Buhler, Douglas; and Gunsolus, Jeffrey, "Velvetleaf (Abutilon theophrasti) Recruitment, Survival,Seed Production, and Interference in Soybean (Glycine max)" (1995). Agronomy \& Horticulture -- Faculty Publications. 619.

https://digitalcommons.unl.edu/agronomyfacpub/619

This Article is brought to you for free and open access by the Agronomy and Horticulture Department at DigitalCommons@University of Nebraska - Lincoln. It has been accepted for inclusion in Agronomy \& Horticulture -Faculty Publications by an authorized administrator of DigitalCommons@University of Nebraska - Lincoln. 


\title{
Velvetleaf (Abutilon theophrasti) Recruitment, Survival, Seed Production, and Interference in Soybean (Glycine max) ${ }^{1}$
}

\author{
JOHN L. LINDQUIST, BRUCE D. MAXWELL, DOUGLAS D. BUHLER, and JEFFREY L. GUNSOLUS ${ }^{2}$
}

\begin{abstract}
Field studies were conducted at Rosemount, $\mathrm{MN}$, in 1992 and 1993 to quantify the demographic processes regulating the population dynamics of velvetleaf in soybean as part of a corn-soybean rotation. A consistent $6.8 \pm 0.5 \%$ of the total velvetleaf seedbank emerged each year. Less than $21 \%$ of all velvetleaf seedlings survived each year in mixture with soybean, due in part to Verticillium spp wilt infection. The probability of seedling survival varied across time of emergence. Velvetleaf seed production in the absence of crop competition was 125 and 227 seeds plant ${ }^{-1}$ in 1992 and 1993, respectively. Velvetleaf plants that emerged early produced greater numbers of seed than later emerging plants. Velvetleaf survival and seed production were reduced up to $82 \%$ in the presence of crop competition. Soybean yield varied across soybean densities in both years, but was not reduced across velvetleaf densities. Nomenclature: Velvetleaf, Abutilon theophrasti Medicus. $\#^{3}$ ABUTH; soybean, Glycine max (L.) Merr. 'Evans'; corn, Zea mays $\mathrm{L}$.

Additional index words. Weed demography, emergence, weed seedling mortality, modeling, Verticillium, ABUTH.
\end{abstract}

\section{INTRODUCTION}

Crop yield loss due to weed interference is the economic foundation of weed science (33). Herbicides have largely been developed to eliminate yield loss due to weed interference. Despite heavy use of herbicides in recent decades, crop losses from weed interference in agriculture continue (13) due to genetic diversity, high seed production, and morphological and physiological adaptability of weedy species. While herbicides may be highly effective at reducing weed populations, their continued use is often offset by increased frequency of more tolerant weed species (14) or by the development of herbicide resistance $(16,25)$. Restrictions due to government regulation and public pressure may severely reduce the available chemical weed control options in the near future $(1,6,16,24,34,44)$. Thus there is growing need for the development of cost effective, environmentally safe, alternative weed management strategies.

\footnotetext{
${ }^{1}$ Received for publication May 18, 1994 and in revised form November 15, 1994. Contribution No. 21,186 from the Minnesota Agric. Exp. Stn., St. Paul, MN 55108.

${ }^{2}$ Former Grad. Res. Asst., Dep. Agron. Plant Gen., Univ. Minnesota, St. Paul, MN 55108; Asst. Prof., Plant, Soil and Environ. Sci. Dep., Montana State Univ., Bozeman, MT 59717; Res. Agron., U.S. Dep. Agric., Agr. Res. Serv., National Soil Tilth Lab., Ames, IA, 50011; and Assoc. Prof., Dep. Agron. Plant Gen., Univ. Minnesota, St. Paul, MN 55108. Current address of first author: Dept. Agron., Univ. Nebraska, Lincoln, NE 68583.

${ }^{3}$ Letters following this symbol are a WSSA-approved computer code from Composite List of Weeds, Revised 1989. Available from WSSA, 1508 West University Ave., Champaign, IL 61820-3133.
}

However, these strategies require a detailed quantitative understanding of the factors regulating the growth and population dynamics of weeds.

The use of economic thresholds to determine when a herbicide application is warranted has gained attention (28) as a potential method of reducing herbicide use while minimizing economic loss. However, single-year economic thresholds do not adequately account for the impact of weed seed production on weed populations in subsequent years (29). Effective use of economic threshold theory in weed management can only be achieved when an accurate, quantitative understanding of the factors that regulate weed population dynamics across growing seasons is obtained.

The population dynamics of an annual weed are regulated by five demographic processes: seedling recruitment and survival, seed production, dispersal, and seed survival in soil $(12,23)$. A schematic diagram of the population dynamics of an annual weed is shown in Figure 1. The boxes in Figure 1 represent state variables and can be measured in the field. The valve symbols represent the five demographic processes, each of which may be influenced by a number of factors including competition, predation (by herbivore or pathogen), and migration. These processes can be represented by biologically realistic equations that quantify the rate of transition from one state to another.

Several studies have been conducted to quantify the demographics of annual weeds in cereal crops $(8,11,12,13,17,42)$.

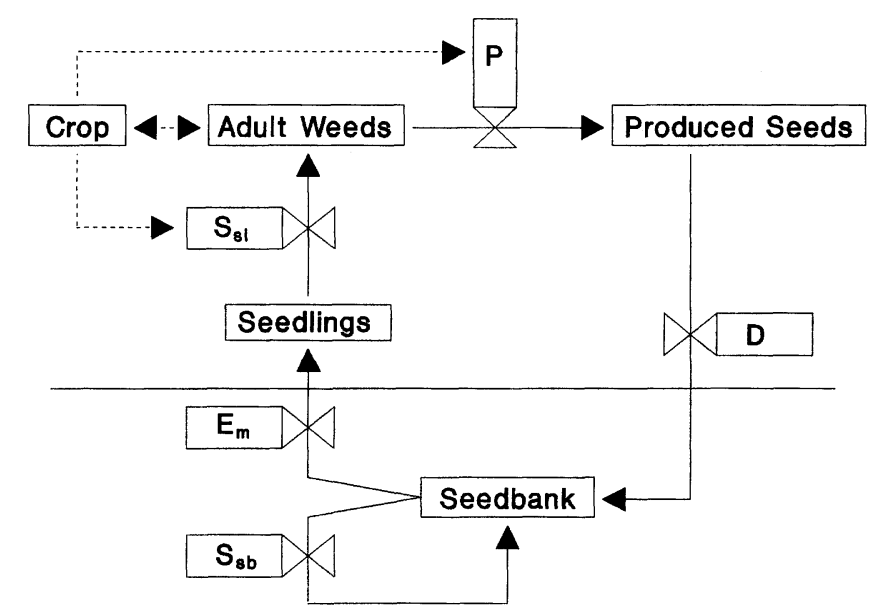

Figure 1. A schematic diagram of the population dynamics of an annual weed. Boxes and valves represent measurable state variables and demographic process variables, respectively. $\mathrm{E}_{\mathrm{m}}=$ recruitment, $\mathrm{S}_{\mathrm{sl}}=$ seedling survival, $\mathrm{P}=$ seed production, $\mathrm{D}=$ dispersal, and $\mathrm{S}_{\mathrm{sb}}=$ seed survival in the seedbank. Dashed arrows indicate that the crop may influence the weed population at these stages. Redrawn from Kropff and Lotz (23). 
However, few data are available to quantify these demographic parameters for most weed species important in corn and soybean in the U.S. corn belt.

Velvetleaf is a major weed in corn and soybean (41), infesting more than 9 million ha of soybean with an annual control cost of $\$ 225$ million (40). Bauer and Mortensen (3) developed a model to calculate the economic optimum threshold for velvetleaf in soybean based upon the population dynamics of velvetleaf. These authors indicated that the primary weakness of their model was the limited biological data available for accurate parameterization.

In this research, five demographic parameters regulating the population dynamics of velvetleaf in soybean as part of a cornsoybean rotation were quantified using data obtained from field experiments conducted over two growing seasons. Additionally, soybean yield as a function of soybean and velvetleaf density was quantified.

\section{MATERIALS AND METHODS}

General procedures. Experiments were conducted within adjacent fields at the University of Minnesota Agricultural Research Station near Rosemount, MN, in 1992 and 1993 on a Waukegan silt loam soil (fine-silty over sandy, mixed, mesic Typic Hapludoll) with 6.5\% organic matter. In 1991 and 1992, 72 (25 $\mathrm{m}^{2}$ ) plots were seeded (by Bussler, 7) with corn and velvetleaf at a range of densities using a randomized complete block design with three replicates. These experiments served as templates for our experiments in 1992 and 1993, when plots were relocated.

Fields were disked twice in the autumn and twice for spring seedbed preparation. Potassium was applied $\left(60 \mathrm{~kg} \mathrm{ha}^{-1}\right)$ to the field in 1992, and no fertilizer was applied in 1993, as recommended by the University of Minnesota Soil Testing Laboratory. Soybean (cv. Evans) row spacing treatments of no crop, 24, 36, and $72 \mathrm{~cm}$ between rows were seeded on May 18, 1992, and May 13,1993 . Soybean sowing density within a row was held constant across treatments at 33 plants $\mathrm{m}^{-1}$ row, so spacing and population density were confounded. Three plots per block (one plot for each row spacing treatment) were randomly selected and hand weeded for weed-free controls. Three plots per block were also randomly selected and hand weeded for crop-free velvetleaf monoculture controls. In all plots, grass weeds were controlled with metolachlor [2-chloro- $N$-(2-ethyl-6-methylphenyl)- $N$-(2methoxy-1-methylethyl)acetamide] applied preplant incorporated at $2.2 \mathrm{~kg} \mathrm{ha}^{-1}$, and other weeds were removed as needed by hand. No precipitation was measured within five days prior to planting in 1992, so approximately $1.2 \mathrm{~cm}$ of water was applied through sprinkler irrigation $2 \mathrm{~d}$ after planting to obtain uniform crop and weed emergence. Subsequent irrigation was not necessary in 1992 or 1993.

Wilt symptoms were observed in the velvetleaf populations in both years of this study. Randomly selected velvetleaf plant samples were submitted to the University of Minnesota Plant Disease Clinic in 1992, and Verticillium (species unknown) was isolated through culture of stem and root tissue. The soybeans showed no symptoms of wilt and were not tested for Verticillium infection.

Seedbank estimates. Velvetleaf seedbank estimates were obtained on May 5, May 20, and August 20, 1992, and on May 19 and August 18,1993 , by removing $16(1.9 \mathrm{~cm}$ diam.) soil cores to a depth of $20 \mathrm{~cm}$ in each plot. The 16 samples from each plot were pooled, bagged, and stored in a dryer until they could be wet sieved with a fine mesh screen and the velvetleaf seeds separated by hand and counted (22). Viability of recovered seeds was virtually $100 \%$, determined by applying a tetrazolium test to a subsample of 300 seeds.

Velvetleaf seedling emergence and survival. Immediately after planting, permanent subplots were established within each plot using three randomly placed wire rings $\left(1.0 \mathrm{~m}^{2}\right.$ total area). Within subplots, velvetleaf seedling emergence was measured by regularly counting and marking newly emerged seedlings with colored wire. A different color of wire was used at each sampling date (ca. weekly). Velvetleaf plants marked with the same color wire belonged in the same cohort. Seedling mortality was measured by counting and removing wires that no longer marked live seedlings at each sampling date. Seedling survival as a function of time of emergence was interpolated from seedling mortality.

In 1992, the first cohort of velvetleaf seedlings was very large. To ensure that velvetleaf populations were not excessive, bentazon [3-(1-methylethyl)-(1H)-2,1,3-benzothiadiazin-4(3H)-one 2,2-dioxide] was applied POST at $1.1 \mathrm{~kg} \mathrm{ha}^{-1}$ to control the first flush only. Mortality due to the treatment was determined as described above. Mortality of velvetleaf seedlings emerging after the 1992 bentazon treatment was high due to wilt. Therefore, no POST velvetleaf control was practiced in 1993.

Velvetleaf seed production. Within each subplot, velvetleaf seed capsules were removed as they matured. In 1992, the capsules per subplot were pooled and the number of lobes per capsule counted. Total seed production per subplot was calculated as the product of the total number of lobes per subplot and the estimate of 2.95 seeds per lobe (obtained by counting the number of lobes and seeds per capsule in a representative subsample of 20 capsules). In 1993, seed production was quantified for each cohort by removing capsules separately among the different seedling cohorts within each subplot.

Soybean yield. Soybean yield was measured on October 2, 1992, and October 11, 1993, by cutting plants at the soil surface in subplots and threshing in the field. The resulting grain was then bagged, dried at $60 \mathrm{C}$ for $7 \mathrm{~d}$, cleaned, and weighed.

Statistical analysis. The objective of this research was to quantify demographic processes via the relationships between measured state variables. Thus, wherever possible, biologically realistic equations were used to characterize relationships, and parameter estimates were obtained using SAS (36) NLIN and REG procedures. Data were pooled across years if parameter estimates were not significantly different (evaluated by comparing $95 \%$ confidence intervals). Where a nonlinear equation was fit to the data, an approximate $r^{2}$ value was obtained by subtracting the ratio of the residual sums of squares (RSS) to the corrected total sums of squares (CTSS) from 1 (i.e., $r^{2}=1-$ 
LINDQUIST ET AL.: VELVETLEAF IN SOYBEAN

Table 1. Cumulative velvetleaf seedling emergence in relation to days after planting (DAP) and growing degree days (GDD) accumulated beginning May 1 in 1992 and 1993.

\begin{tabular}{|c|c|c|c|c|c|}
\hline \multicolumn{3}{|c|}{1992} & \multicolumn{3}{|c|}{1993} \\
\hline & $\mathrm{C}$ & $\%$ & & $\mathrm{C}$ & $\%$ \\
\hline 0 & 144 & 0.0 & 0 & 84 & 0.0 \\
\hline 8 & 203 & $48.1 \pm 7.9$ & 7 & 116 & $1.5 \pm 1.8$ \\
\hline 18 & 289 & $67.9 \pm 7.7$ & 19 & 173 & $36.0 \pm 10.3$ \\
\hline 28 & 392 & $78.3 \pm 6.6$ & 26 & 223 & $52.4 \pm 11.8$ \\
\hline 57 & 637 & $99.2 \pm 1.6$ & 46 & 407 & $95.0 \pm 4.5$ \\
\hline 64 & 697 & $99.3 \pm 1.5$ & 54 & 488 & $98.7 \pm 1.7$ \\
\hline 71 & 753 & $99.4 \pm 1.3$ & 68 & 635 & $99.4 \pm 1.3$ \\
\hline 78 & 809 & $99.5 \pm 1.2$ & 85 & 808 & $99.8 \pm 0.7$ \\
\hline 86 & 896 & $99.7 \pm 0.5$ & 110 & 1107 & $100 \pm 0.0$ \\
\hline 100 & 1012 & $100 \pm 0.0$ & & & \\
\hline
\end{tabular}

${ }^{\mathrm{a}}$ Mean \pm one standard deviation $(\mathrm{n}=69)$.

${ }^{b}$ Mean \pm one standard deviation $(n=72)$.

RSS/CTSS). Where pairwise comparisons of means were made, SAS GLM procedure was used because sample size differed among treatments.

\section{RESULTS AND DISCUSSION}

Recruitment. Velvetleaf seedling emergence began immediately after planting in 1992, but was delayed by approximately $10 \mathrm{~d}$ in 1993 (Table 1). Variable seed germination induced by environmental conditions may explain the difference in cumulative emergence in 1992 and 1993. Hard-seededness has been suggested as a mechanism for velvetleaf seed dormancy, and seasonal regulation of dormancy may result from alternate freeze-thawing and wetting-drying cycles (41). Emergence might, therefore, be expected to respond to moisture and accumulated heat units (2). Using irrigation to ensure uniform emergence of the soybeans in 1992 also may be responsible for the earlier velvetleaf emergence in 1992 compared to 1993. Differences in cumulative emergence patterns across years were not as great when related to growing degree days (GDD, base $10 \mathrm{C}$, maximum $30 \mathrm{C}$ ) accumulated from May 1 rather than days after planting (DAP, Table 1).

Total seedling emergence as a function of the spring seedbank estimates in 1992 and 1993 are shown in Figure 2. While Harper (19) suggests that density dependent emergence is possible due to the frequency of 'safe sites' being limited, such a response was not observed. A linear regression was therefore fit to the data. Parameter estimates were not significantly different between years so data were pooled for the analysis shown in Figure 2. The slope parameter of $0.068 \pm 0.005$ indicates that a consistent 6.8 $\pm 0.5 \%$ of the velvetleaf seedbank emerged each year. This value is about $2 \%$ higher than the values reported for velvetleaf by Pacala and Silander (31). Seed predation, micro-environmental variability, and genetic differences in seed dormancy were not measured but may contribute, along with seedbank sampling error, to the observed variation in emergence and its relationship with seedbank counts.

The relationships in Table 1 and Figure 2 provide an estimate of velvetleaf seedling recruitment $\left(\mathrm{E}_{\mathrm{m}}\right.$ in Figure 1). Roberts and Dawkins (35) suggest that the rate of recruitment may be constant under a consistent cultivation regime. Therefore these data may be used to estimate velvetleaf seedling population density based on known seedbank population densities.

Seedling survival. Wilted leaves, a characteristic symptom of Verticillium infection (37), were observed on nearly all velvetleaf seedlings in both years, despite wet soil conditions. Often the entire plant wilted and died, thus Verticillium was an important factor in velvetleaf seedling survival. Percent survival of velvetleaf seedling cohorts in velvetleaf monoculture plots or in

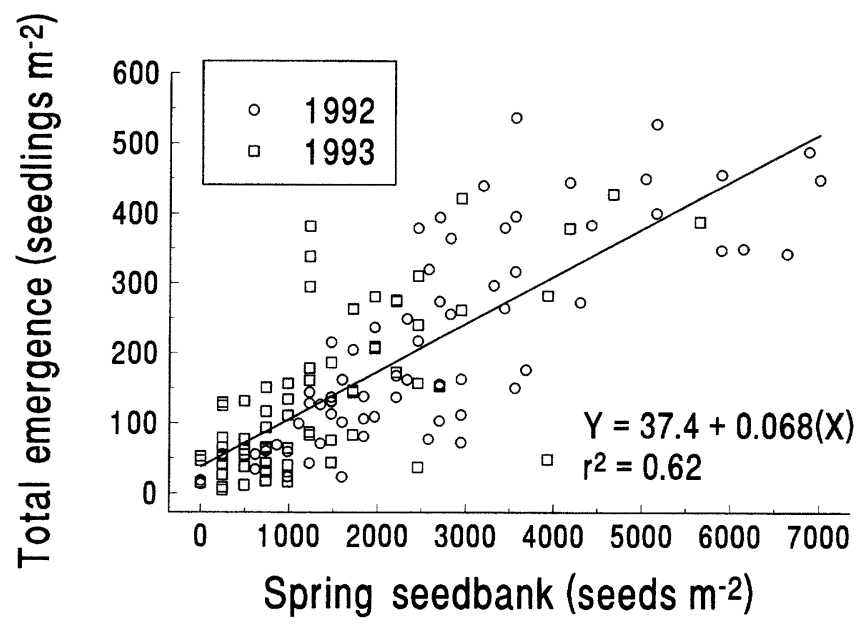

Figure 2. Total cumulative velvetleaf emergence as a function of the spring seedbank estimate in 1992 and 1993. The slope provides an estimate of the proportion of the seedbank that emerges each year. The root mean square error (RMSE) of the regression is $84(n=139)$. 
Table 2. Percent velvetleaf seedling survival by time of emergence (DAP) in monoculture $(V, n=9)$ and in mixture with soybean $(V+S, n=63)$.

\begin{tabular}{|c|c|c|c|c|c|}
\hline \multicolumn{3}{|c|}{1992} & \multicolumn{3}{|c|}{1993} \\
\hline DAP & V & $\mathrm{V}+\mathrm{S}$ & DAP & V & $\mathrm{V}+\mathrm{S}$ \\
\hline & & & & & 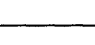 \\
\hline 8 & 12.03 & $12.03^{\mathrm{a}}$ & 7 & 25.92 & 20.74 \\
\hline 18 & 2.89 & 4.03 & 19 & 57.97 & $14.64 *$ \\
\hline 28 & 3.35 & 1.62 & 26 & 52.48 & $10.31 *$ \\
\hline 36 & 11.38 & $2.44 *$ & 33 & 61.32 & $10.12^{*}$ \\
\hline 50 & 5.40 & 1.67 & 40 & 52.24 & $7.09 *$ \\
\hline 57 & 3.70 & 1.67 & 46 & 33.79 & $4.67^{*}$ \\
\hline 64 & 22.22 & $0.00 *$ & 54 & 57.26 & $2.84^{*}$ \\
\hline 71 & 5.56 & 3.33 & 68 & 14.81 & 3.31 \\
\hline 78 & 6.94 & 1.67 & 85 & 14.81 & 3.70 \\
\hline 86 & 30.99 & $0.00 *$ & & & \\
\hline 100 & 18.52 & $1.67 *$ & & & \\
\hline $\operatorname{LSD}^{\mathrm{c}}$ & 21.19 & 3.74 & LSD & 30.41 & 7.04 \\
\hline
\end{tabular}

${ }^{\text {aPercent }}$ of velvetleaf seedlings surviving the bentazon treatment.

${ }^{b} \mathrm{An}$ asterisk indicates values within a row for each year are significantly different at the $\mathrm{p}<0.05$ probability level.

'Tukey's Least Significant Difference (at $\mathrm{p}<0.05$ ) value for comparisons within a column.

mixture with soybean are shown in Table 2 . In both years, velvetleaf seedling survival was reduced in the presence of soybean, greater decreases occurring with later cohorts. The reduction in velvetleaf survival in mixture with soybean may be due to competition for light because complete canopy closure occurred within 40 to $50 \mathrm{~d}$ after planting (DAP) in the mixed stand plots. Survival in velvetleaf monoculture plots was independent of time of cohort emergence, perhaps because complete canopy closure never occurred in either year, despite very high population densities in some plots. Velvetleaf survival in mixture with soybean was relatively consistent across soybean densities and years, whereas survival in velvetleaf monoculture plots was about 9\% higher in 1993.

Results show that soybean may have a substantial negative influence on velvetleaf survival, though the relative importance of the crop in reducing velvetleaf survival may be confounded by the influence of Verticillium. The potential impact of soybean on velvetleaf seedling survival in conditions where wilt is not present is worthy of further investigation.

Data reported in Table 2 represent estimates of velvetleaf seedling survivorship ( $\mathrm{S}_{\mathrm{sl}}$ in Figure 1), and may be used to estimate the mature velvetleaf population density from known seedling population densities. Because velvetleaf seedling survival did not show clear density dependence and varied considerably as a function of time of emergence (Table 2), maximum survivorship in the presence of the crop may provide the most conservative estimate for modeling mature velvetleaf population densities.

Seed production. Multiple regression analysis was used to determine the influence of velvetleaf density $\left(\mathrm{N}_{\mathrm{w}}\right)$, soybean density $\left(\mathrm{N}_{\mathrm{c}}\right.$ ), and year on velvetleaf seed production (results not shown). Seed production was reduced by soybean interference,
Table 3. Velvetleaf seed production across years in monoculture $(\mathrm{V}, \mathrm{n}=19)$ and in mixture with soybean $(V+S, n=93)$.

\begin{tabular}{|c|c|c|c|}
\hline Year & $\mathrm{V}$ & $V+S$ & \\
\hline & $\longrightarrow$ & seeds plant ${ }^{-1}$ & $\mathrm{LSD}^{\mathrm{a}}$ \\
\hline 1992 & 124.65 & 40.37 & 69.79 \\
\hline 1993 & 226.78 & 48.93 & 74.28 \\
\hline $\operatorname{LSD}^{\mathrm{b}}$ & 91.00 & 42.23 & \\
\hline
\end{tabular}

${ }^{a}$ Tukey's Least Significant Difference (at $\mathrm{p}<0.05$ ) for comparisons within a row.

${ }^{b}$ Tukey's Least Significant Difference (at $\mathrm{p}<0.05$ ) for comparisons within a column.

but was not influenced by velvetleaf density or year. A consistent relationship (e.g., hyperbolic) between velvetleaf seed production and soybean density was not found. Soybean densities were combined, and a pairwise comparison of velvetleaf seed production across years in monoculture and in mixture with the crop was made (Table 3 ).

Data presented in Table 3 represent the seed productivity ( $P$ in Figure 1) of a Verticillium-infected velvetleaf population and may be used to estimate the number of seeds produced (the seed rain) by a known population of mature infected velvetleaf plants. By comparison, Munger et al. (27) observed high velvetleaf seed production in one year of their study ( 770 seeds plant ${ }^{-1}$ in mixture with soybean), and low values in the other year ( 17 seeds plant $^{-1}$ in mixture). They attributed the low seed production to interspecific competition for water. Zanin and Sattin (45) observed high velvetleaf seed production ( 3379 and 4520 seeds plant $^{-1}$ ) when grown in mixture with maize in Italy.

The use of a constant seed production value or relationship within a population dynamics model requires the assumption that all mature plants are identical in their ability to produce seed. In real populations, a natural hierarchy of plant sizes occurs as a result of differences in relative emergence time, seed size, micro-environment, and genetic variation $(32,43)$. Because plant size is often correlated with seed production (39), it is important to consider the factors that determine which plants become large. If we assume a plant that is large relative to its neighbors at some early stage of growth will remain large (as did Pacala and Weiner, 32 ), then it may also be assumed that the earliest emerging plants will have an inherent advantage over later emerging individuals, and therefore will be responsible for producing greater numbers of seed. Table 4 shows the 1993 velvetleaf seed production by cohort in monoculture and in mixture with soybean. Seedlings emerging between 8 and 33 DAP produced greater numbers of seed than the earliest or later emerging velvetleaf cohorts. As with seedling survival, seed production was reduced in the presence of soybean, though the relative importance of the crop in reducing velvetleaf seed production may be confounded by the influence of Verticillium.

Soybean yield. Soybean yield was not reduced by velvetleaf density in either year (Figure 3a). Other research has documented substantial soybean yield loss due to velvetleaf competition (4, $5,10,18,20,27,30)$. The lack of velvetleaf competitiveness 
Table 4. Velvetleaf seed production $\left(\right.$ plant $\left.^{-1}\right)$ by cohort in monoculture $(\mathrm{V}, \mathrm{n}=9)$ and in mixture with soybean $(V+S, n=31)$. Data are from 1993 field season only.

\begin{tabular}{|c|c|c|}
\hline DAP & V & $\mathrm{V}+\mathrm{S}$ \\
\hline & & \\
\hline 7 & 0.04 & 0.01 \\
\hline 19 & 132.09 & $44.26^{*}$ \\
\hline 26 & 81.52 & $15.06^{*}$ \\
\hline 33 & 113.10 & $5.61^{*}$ \\
\hline 40 & 24.84 & $0.83^{*}$ \\
\hline 46 & 9.40 & 0.00 \\
\hline 54 & 6.50 & 0.00 \\
\hline 68 & 0.00 & 0.00 \\
\hline $\operatorname{LSD}^{b}$ & 74.39 & 29.83 \\
\hline
\end{tabular}

${ }^{\mathrm{a}} \mathrm{An}$ asterisk indicates values within a row are significantly different at the $\mathrm{p}$ $<0.05$ probability level.

${ }^{\mathrm{b}}$ Tukey's Least Significant Difference (at $\mathrm{p}<0.05$ ) for comparisons within a column.

observed in this study is assumed to be the result of infection by Verticillium.
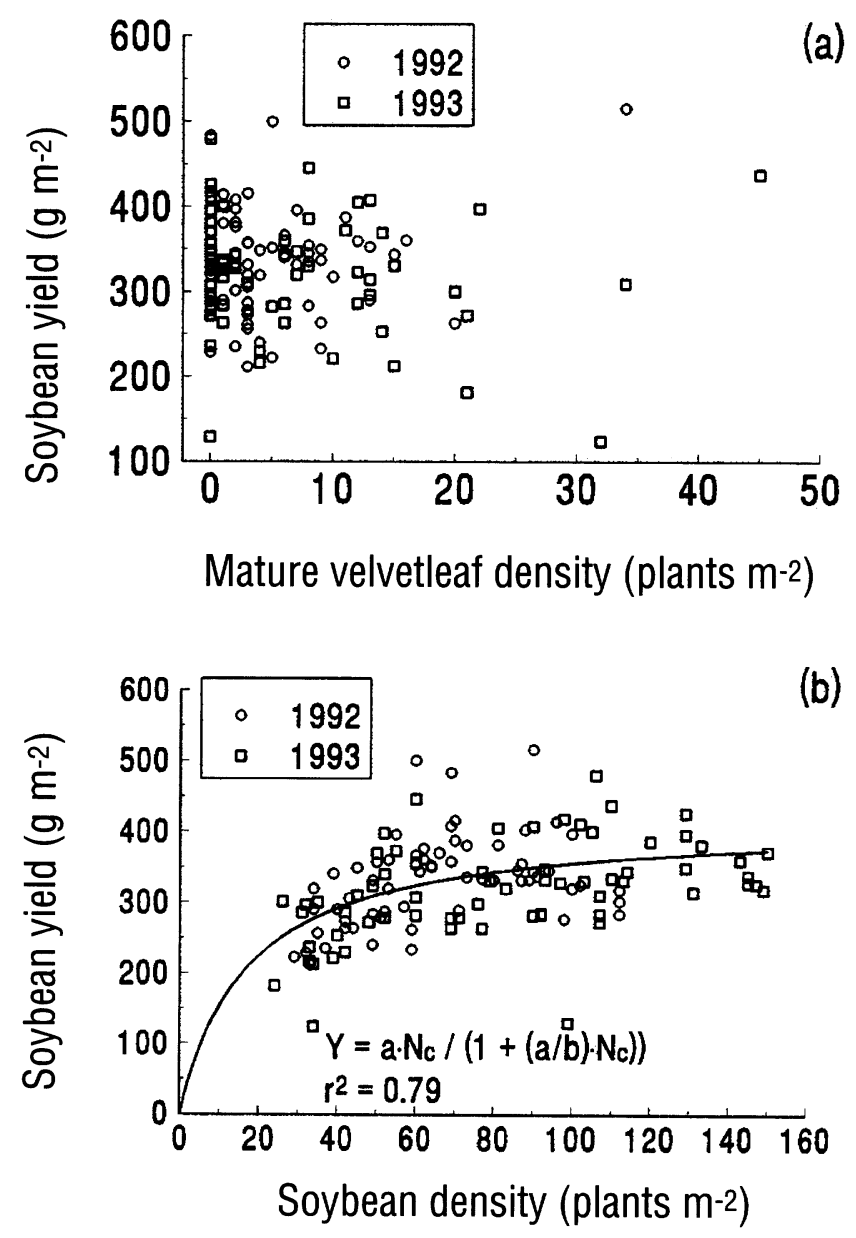

Figure 3. Soybean yield as a function of velvetleaf density (a) and soybean $\left(\mathrm{N}_{\mathrm{c}}\right)$ density (b). For (b), parameter estimates are $a=24.39$ and $b=415.1$. The RMSE of the regression is $62(n=147)$.
Soybean yield as a function of soybean density was quantified using a hyperbolic function (modified from Cousens, 8). Parameter estimates were not significantly different across years so data were pooled (Figure $3 b$ ). Soybean yield increased with increasing soybean density (decreasing row spacing) treatments.

Seed dispersal and survival in soil. Figure 4 shows the $\mathrm{Au}-$ gust seedbank (pre-seed rain) estimate plotted against the spring seedbank (postemergence) estimate. The slope of the linear regression provides an estimate of the proportion of seeds not emerging that survive through the growing season in soil (a part of $S_{\mathrm{sb}}$ in Figure 1). Slope values were not significantly different across years so data were pooled. Results show $70 \pm 6 \%$ of all seeds that do not emerge survive through August in soil. Fifty one percent of the residual variation in the August seedbank estimate was accounted for by the linear model.

The spring 1993 seedbank estimate is plotted against the autumn 1992 seedbank estimate (August seedbank plus 1992 seed rain) in Figure 5. The slope estimate of this relationship provides an estimate of the density-independent overwintering survival of both newly dispersed seeds and those already in the seedbank. Results show $29 \pm 3 \%$ of seeds within soil in the autumn will survive through the next spring. Forty-six percent of the residual variation in spring seedbank estimate was accounted for by the model.

Much of the observed variation in seedbank estimates was the result of predation (herbivory and pathogens), micro- and macroenvironment, machinery-induced migration, and the interaction among these factors $(19,21,26,38)$.

The relationships in Figures 4 and 5 provide a combined estimate of dispersal and seed survival in soil ( $D$ and $S_{\mathrm{sb}}$ in Figure 1), and may be used to estimate the spring seedbank population density based on known seed rain and seedbank population density in the previous year.

Verticillium may have a significant impact on velvetleaf seedling survival, seed production, and competitive ability. A nega-

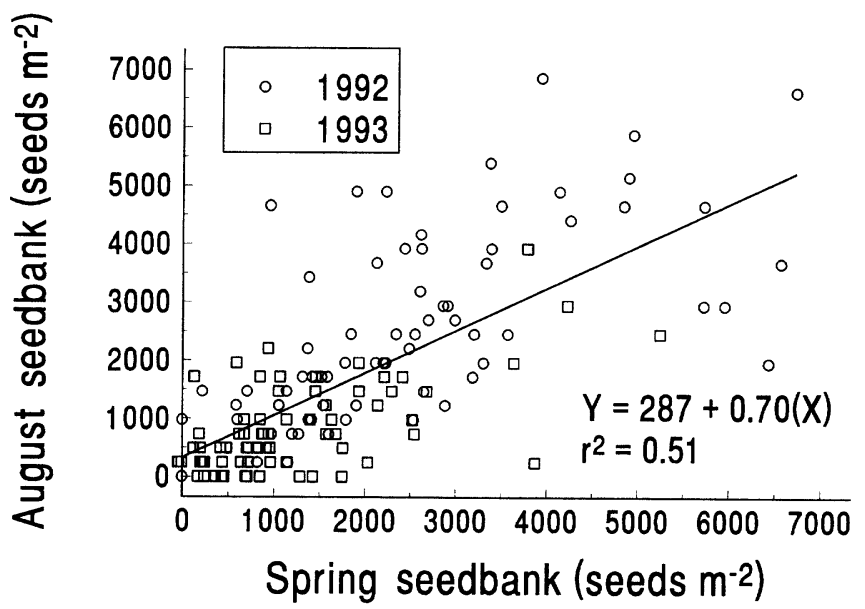

Figure 4. August seedbank estimate as a function of the corrected spring seedbank estimate (measured spring seedbank less total emergence). The slope provides an estimate of seed survival in soil through the growing season. The RMSE of the regression is $1079(n=139)$. 


\section{WEED SCIENCE}

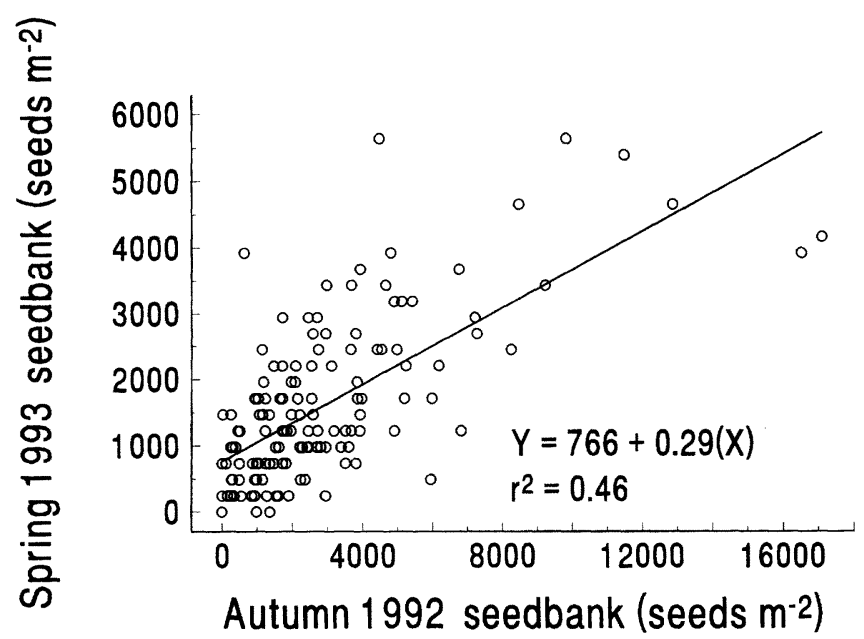

Figure 5. Spring 1993 seedbank estimate as a function of the corrected 1992 autumn seedbank estimate (measured August seedbank plus seed rain). The slope provides an estimate of the overwintering survival of seeds in the autumn seedbank. The RMSE of the regression is $898(n=139)$.

tive influence of Verticillium species on velvetleaf has been documented previously $(37,41)$. Green and Wiley $(15)$ suggested Verticillium dahliae might be useful as a biological control agent for velvetleaf, but Sickinger (37) found that some soybean varieties were also sensitive to $V$. dahliae when inoculated in the greenhouse. Our results show that while velvetleaf was sensitive to Verticillium in the field, soybean (cv. Evans) showed no sensitivity. Further research on the potential use of Verticillium species as a velvetleaf biocontrol agent in field situations is warranted.

Quantitative estimates of the five demographic processes obtained from this research may be useful for building a simple two-species population dynamics model of velvetleaf in soybean. The population dynamics of Verticillium-infected velvetleaf as predicted by such a model should be compared to the predicted dynamics of noninfected velvetleaf using alternative survival, seed production, and competitiveness data. Such an analysis may provide considerable insight into the potential economic and environmental benefit of using a biological control agent to regulate velvetleaf population growth and interference with soybean.

\section{ACKNOWLEDGEMENTS}

We thank E. Ristau for his field assistance and D. Andow, O. Burnside, and R. Becker for valuable comments on early drafts. This research was supported in part by USDA-ARS Cooperative Agreement titled "Validation of Weed Management Expert Systems for Corn and Soybeans."

\section{LITERATURE CITED}

1. Abernathy, J. R. 1992. Winds of change. Weed Technol. 6:760-764.
2. Alm, D. M., E. W. Stoller, and L. M. Wax. 1993. An index model for predicting seed germination and emergence rates. Weed Technol. 7:560569.

3. Bauer, T. A. and D. A. Mortensen. 1992. A comparison of economic and economic optimum thresholds for two annual weeds in soybeans. Weed Technol. 6:228-235.

4. Bauer, T. A., D. A. Mortensen, G. A. Wicks, T. A. Hayden, and A. R. Martin. 1991. Environmental variability associated with economic thresholds for soybeans. Weed Sci. 39:564-569.

5. Begonia, G. B., R. J. Aldrich, and C. D. Salisbury. 1991. Soybean yield and yield components as influenced by canopy heights and duration of competition of velvetleaf (Abutilon theophrasti Medik.). Weed Res. 31:117124.

6. Burnside, O.C. 1993. Weed science-The step child. Weed Technol. 7:515518.

7. Bussler, B. H. 1993. Corn interactions with common cocklebur and velvetleaf. Ph.D. Thesis, University of Minnesota, St. Paul MN, 103 pp.

8. Cousens, R. 1985. A simple model relating yield loss to weed density. Ann. Appl. Biol. 107:239-252.

9. Cousens, R., C. J. Doyle, B. J. Wilson, and G. W. Cussans. 1986. Modelling the economics of controlling Avena fatua in winter wheat. Pestic. Sci. 17:1-12.

10. Dekker, J. and W. F. Meggitt. 1983. Interference between velvetleaf (Abutilon theophrasti Medic.) and soybean (Glycine $\max (\mathrm{L})$. Merr.). I. Growth. Weed Res. 23:91-101.

11. Doyle, C. J., R. Cousens, and S. R. Moss. 1986. A model of the economics of controlling Alopecurus myosuroides Huds. in winter wheat. Crop Prot. 5:143-150.

12. Fernandez-Quintanilla, C., L. Navarette, J. L. G. Anduajar, A. Fernandez, and M. J. Sanchez. 1986. Seedling recruitment and age-specific survivorship and reproduction in populations of Avena sterilis L. ssp. ludoviciana (Durieu) Nyman. J. Appl. Ecol. 23:945-955.

13. Firbank, L. G. and A. R. Watkinson. 1986. Modelling the population dynamics of an arable weed and its effects upon crop yield. J. Appl. Ecol. 23:147-159.

14. Fryer, J. D. and R. J. Chancellor. 1970. Evidence of changing weed populations in arable land. Proc. British Weed Control Conf. 10:958-964.

15. Green, R. J. and G. L. Wiley. 1987. Verticillium dahliae as a biocontrol agent of velvetleaf, Abutilon theophrasti. Can. J. Plant Path. 9:81.

16. Gressel, J. 1992. Addressing real weed science needs with innovations. Weed Technol. 6:509-525.

17. Gonzalez-Andujar, J. L. and C. Fernandez-Quintanilla. 1991. Modelling the population dynamics of Avena sterilis under dry-land cereal cropping systems. J. Appl. Ecol. 28:16-27.

18. Hagood Jr., E. S. 1980. Growth analysis and growth simulation of soybeans in competition with velvetleaf and jimsonweed. Ph. D. Thesis, Purdue University, West Lafayette IN, $137 \mathrm{pp}$.

19. Harper, J. L. 1977. Population biology of plants. Academic Press, London UK.

20. Hayden, T. A. 1988. Interference of common sunflower, tall waterhemp and velvetleaf in soybeans and growth and herbicide response of selected pigweed species. Ph. D. Thesis, University of Nebraska, Lincoln NE, $108 \mathrm{pp}$.

21. Howard, C. L., A. M. Mortimer, P. Gould, P. D. Putwain, R. Cousens, and G. W. Cussans. 1991. The dispersal of weeds: Seed movement in arable agriculture. Brighton Crop Protection Conference: Weeds 6C-5:821-828.

22. Khedir, K. D. and F. W. Roeth. 1981. Velvetleaf (Abutilon theophrasti) seed populations in six continuous corn (Zea mays) fields. Weed Sci. 29:485-490.

23. Kropff, M. J. and L. A. P. Lotz. 1992. Optimization of weed management systems: the role of ecological models of interplant competition. Weed Technol. 6:462-470.

24. Liebman, M. and E. Dyck. 1993. Weed management: A need to develop ecological approaches. Ecol. Appl. 3:39-41.

25. Maxwell, B. D., M. L. Roush, and S. R. Radosevich. 1990. Predicting the evolution and dynamics of herbicide resistant weed populations. Weed Technol. 4:2-13.

26. McCanny, S. J. and P. B. Cavers. 1988. Spread of proso millet (Panicum miliaceum L.) in Ontario, Canada. 2. Dispersal by combines. Weed Res. 28:67-72. 


\section{LINDQUIST ET AL.: VELVETLEAF IN SOYBEAN}

27. Munger, P. H., J. M. Chandler, J. T. Cothren, and F. M. Hons. 1987. Soybean (Glycine max) - velvetleaf (Abutilon theophrasti) interspecific competition. Weed Sci. 35:647-653.

28. Norris, R. F. 1992. Ecological perspectives on utility of thresholds for weed management. Weed Technol. 6:182-183.

29. Norris, R. F. 1992. Case history for weed competition/population ecology: Barnyardgrass (Echinochloa crus-galli) in sugarbeets (Beta vulgaris). Weed Technol. 6:220-227.

30. Oliver, L. R. 1979. Influence of soybean (Glycine max) planting date on velvetleaf (Abutilon theophrasti) competition. Weed Sci. 27:183-188.

31. Pacala, S. W. and J. A. Silander Jr. 1990. Field tests of neighborhood population dynamic models of two annual weed species. Ecol. Monogr. 60:113-134.

32. Pacala, S. W. and J. Weiner. 1991. Effects of competitive asymmetry on a local density model of plant interference. J. Theor. Biol. 149:165-179.

33. Radosevich, S. R. 1987. Methods to study interactions among crops and weeds. Weed Technol. 1:190-198.

34. Radosevich, S. R. and C. M. Ghersa. 1992. Weeds, crops, and herbicides: A modern-day "neckriddle." Weed Technol. 6:788-795.

35. Roberts, H. A. and P. A. Dawkins. 1967. Effects of cultivation on the numbers of viable seeds in soil. Weed Res. 7:290-301.

36. SAS. 1988. SAS/STAT User's Guide, Release 6.03. SAS Institute, Cary NC, $1028 \mathrm{pp}$.
37. Sickinger, S. M. 1981. The effects of Verticillium dahliae (Kleb.) on velvetleaf (Abutilon theophrasti) and crops. M.S. Thesis, Univ. of Wisconsin, Madison. $141 \mathrm{pp}$.

38. Silvertown, J. W. 1987. Introduction to plant population ecology. John Wiley and Sons, New York NY.

39. Solbrig, O. T. 1981. Studies on the population biology of the genus Viola. II. The effect of plant size on fitness in Viola sororia. Evolution 35:10801093.

40. Stoller, E. W., S. K. Harrison, L. M. Wax, E. E. Regnier, and E. D. Nafziger 1987. Weed interference in soybeans (Glycine max). Rev. Weed Sci. 3:155181.

41. Warwick, S. I. and L. D. Black. 1988. The biology of Canadian weeds. 90. Abutilon theophrasti. Can. J. Plant Sci. 68:1069-1085.

42. Watkinson, A. R., W. M. Lonsdale, and M. H. Andrew. 1989. Modelling the population dynamics of an annual plant Sorghum intrans in the wet-dry tropics. J. Ecol. 77:162-181.

43. Weiner, J. 1985. Size hierarchies in experimental populations of annual plants. Ecology 66:743-752.

44. Wyse, D. L. 1992. Future of weed science research. Weed Technol. 6:162165.

45. Zanin, G. and M. Sattin. 1988. Threshold level and seed production of velvetleaf (Abutilon theophrast Medicus) in Maize. Weed Res. 28:347352. 